\title{
Factors that Influence Women in Selected Zongo Communities in Ghana into Skin Bleaching
}

\author{
Samuel Poatob Sharifa Mohammed Mohammed Adam \\ Department of Social Studies Education, University of Education, Winneba, P. O. Box 25
}

\begin{abstract}
The study analysed the factors that influence women in selected Zongo communities (Aboabo, Nima, Sawaba, Asawasi, Madina) in the country into skin bleaching. A sample size of fifteen (15) women who were selected through the purposive sampling technique was used to conduct the study. Interviews (semi-structured interview guide) were used to collect the data necessary for study. The data collected was analysed thematically. They bleach their skins for many reasons including the desire to sustain their marriages, the attempt to treat acne and also as a result of influence from peers among others. It was therefore recommended that the National Commission for Civic Education (NCCE), Food and Drugs Authority, the government and other responsible agents should take up the responsibility of educating Ghanaians on the dangers of skin bleaching.
\end{abstract}

Keywords: Zongo women, Skin bleaching

DOI: $10.7176 /$ RHSS/9-10-03

Publication date:May $31^{\text {st }} 2019$

\section{INTRODUCTION}

\section{Background to the Study}

The art of body beautification is not a new practice in the human society, not even in our Ghanaian society. The science of body beautification has been in existence from time immemorial. In both ancient and medieval times, people have learnt to adorn their bodies in different styles. The quest for beauty and beautiful skin has no limit or restriction and as such extends across race, sex, religion, all age groups and even educational level. However, the degree at which attention is being given to skin beautification which has gradually with the passage of time, turned into skin bleaching calls for a special concern.

Recently, the art of body beautification has progressed from ordinary maintenance of natural complexion to complete skin bleaching; an art of changing the colour of the body to become lighter. Meanwhile, there is a big difference between seeking a glowing, healthy and even-toned skin and an unhealthy fixation on becoming light skinned by using harmful skin products and chemicals (Engema, 2016).

Skin bleaching refers to people's use of home-made, cosmetic or dermatological products over time to remove the melanin from the skin (Charles, 2003). Again, Konlan (2016) refers to skin bleaching as "the practice of using chemical substances in an attempt to lighten skin tone or provide an even skin complexion by reducing the melanin concentration in the skin."

The World Health Organization (2011) defines skin bleaching as the intentional alteration of one's natural skin colour to one relatively, if not substantially lighter in colour, through the use of chemical skin lightening agents, either manufactured, homemade or a combination of the two. Skin bleaching is an old practice which according to Mire (2001) is "linked to the ways in which whiteness historically has come to be viewed as the paradigm, the standard, the universal body while black is seen as deviant, degenerate and ugly."

Skin bleaching of any type is not a practice found among only people with black skin (Africans) but is also a practice even among Asians (Charles, 2003). The practice of skin bleaching in Africa has been attributed to incessant Racism, Colonialism, the Policy of Assimilation as well as the Apartheid in South Africa (Carlos, 2016). While skin bleaching may be prescribed by a dermatologist as remedy for medical problems like hyperpigmentation due to sun damage, skin irritation and effects of using birth control pills, many African men and women do not bleach for these reasons and neither is skin bleaching recommended to them by a dermatologist with the usual prescription of bleaching agent containing less than $2 \%$ of hydroquinone (Engema, 2016).

The practice of skin bleaching has become the vogue among the youth (male and female) and portion of the aged in Ghana and particularly in the Zongo communities; Aboabo, Nima, Asawasi, Sawaba, Madina which is the focus of this study, such that there seem to be a hidden competition between the dark skinned and the fair skinned, where they are both striving to become fair skinned and white respectively. According to Engema (2016), as at 2016, an estimate of $27 \%$ of women worldwide used skin bleaching agents. Meanwhile, Konlan (2016) maintains that the Ghana Health Service reported in 2005 that approximately $30 \%$ of Ghanaian women and $5 \%$ of Ghanaian men were actively involved in skin bleaching as at that time. He again stressed that the statistics have shot up and as at 2016, 50\% - 60\% of adult Ghanaian women not excluding our celebrities who the youth look up to are now or have at one time or the other, actively used bleaching agents which include soaps, creams, and now pills and injections.

The practice of skin bleaching comes along with several effects as a result of the chemical content which 
include mercury and hydroquinone, the two most prominent chemical content of skin bleaching agents. These effects include kidney damage, skin cancer, skin rashes, skin discoloration and scarring as well as reduction in the skin's resistance to bacterial and fungal infections, psychological disorders and body odour (World Health Organisation, 2011; Ananpansah, 2016; Delle, 2016; Mahè et al., 2003).

Despite these dangerous effects associated with skin bleaching, the backlash from social and religious organizations, efforts of the government to reduce skin bleaching which include the August 2016 new ban on hydroquinone, the primary chemical in many skin-bleaching products, as well as the efforts of non-governmental organizations in educating Ghanaians particularly women to desist from the practice, women in the Zongo communities to be specific, seem to be deaf and blind about it and are persistent in practicing it. Not even the popular saying, "black is beautiful" has worked on their minds

The rate at which women, young and old, bleach their skin in the Zongo communities of Ghana is adding up rapidly despite the alarming effects associated with it, the criticism from society and religious institutions as well as the efforts of government and non-governmental organizations alike to reduce, if not completely eliminate the practice of skin bleaching in the society. This has had the government, men and even some women concerned and worried about the health status of women in the Zongo communities and most importantly distressed about the threat this practice of skin bleaching poses on our proud identity as Ghanaians and ultimately as Africans.

The persistence of this practice in spite of its negative impact on the body and even the state of mind prompted the researchers to investigate into the phenomenon to examine what could have been the ideas behind the practice by these women in the Zongo communities.

This research therefore seeks to analyse the factors that influence women in the zongo communities into skin bleaching despite the criticism it is receiving from the society and religious organizations.

\section{REVIEW OF RELATED LITERATURE}

A lot of empirical works have been conducted on the issue of skin bleaching and aspects related to it. The World Health Organization (2011) defines skin bleaching as the intentional alteration of one's natural skin color to one relatively, if not substantially lighter in color, through the use of chemical skin lightening agents either manufactured, homemade or a combination of the two. Olumide (2006) asserts that body bleaching involves the application of substances or solutions that are capable of removing the upper surface of the skin, thereby making the colour of the body become lighter. In the view of Konlan (2016), skin bleaching is the practice of using chemical substances in an attempt to lighten the skin tone or provide an even skin complexion by reducing the melanin concentration in the skin.

The melanin is a dark brown or black substance that is part of people's skin, hair and eyes (MerriamWebster dictionary, 2018). Meanwhile, Engema (2016) also defines the melanin as a brown pigment in the skin which helps protect it against ultraviolet rays of the sun and the dangers associated with it like skin cancer. Dankwah (2005) opines that the basic difference between the black complexion and the white complexion is the melanin content of the skin and that black people have more melanin concentration in their skins than white people. Thus, the higher the content of melanin in one's skin, the darker a person becomes whiles the lower the melanin content in one's skin, the whiter a person turns.

Dangerous chemicals like hydroquinone, mercury, azelaic acid, arbutin, tretinion, kojic acid and niacinamido as identified by Ananpansah (2016) which most bleaching products contain, wears off the melanin content of the black skin when applied on it and turns it white or light depending on the concentration level of the chemical used in the agent of skin bleaching as well as the preference of the individual. These chemicals found in the skin bleaching agents reduce the melanin content by inhibiting tyrosinase, the enzyme which controls melanin production (Engema, 2016). Hydroquinone and mercury are the two most prominent chemical contents found in most bleaching creams. The former is a toxic chemical mostly used in the manufacturing of rubber as well as in black and white film processing as pointed out by Engema (2016).

Previous studies on skin bleaching using qualitative or quantitative approaches have reported vast and diverse motives behind skin bleaching. Mire (2001) identifies the attempt to gain respectability and social mobility within the white supremacist capitalist social and political order as well as the representation of the white body by the dominant culture as the most virtuous and aesthetically most appealing and the dark skin represented as the least virtuous and aesthetically least appealing as some of the factors that influence people into skin bleaching.

In Ghana and particularly in the Zongo Communities, whites do not dominate at all, as such the attempt to gain respectability and social mobility among the whites is not a factor that is applicable in this context. Thus, women in this context cannot be said to be bleaching for this reason.

Ananpansah (2016) was of the same view that, the belief that white or pale skins portray beauty, richness and success and the black complexion considered inferior and below standard is a reason why people bleach their skin. He again assets that most people bleach and prefer lighter skins in order to gain status and recognition in their groups, families and society at large. Again Lewis et al (2011) found out in their study that women in 
Tanzania bleach as a result of the need to be white, beautiful, and more European looking and as a result had embraced more Eurocentric beauty ideals.

Carlos (2016) attributes the practice of skin bleaching by many women to low self-esteem which agrees with Engema (2016) that women bleach as a way of eradicating a sense of insecurity mostly when it comes to their men, unworthiness and low self-esteem. And this reason can be attributed to women in the communities under study. Kpanake et al (2010) further support this motive as they captured in their study that people bleach their skins because they want to have a good image of themselves, to be considered as civil and also to change their physical appearances which they had found not satisfying at all. They described skin bleaching as a way of strengthening the self.

Akerele (2006) believes that the reasons why people bleach is to establish relationships, eradicate racial discrimination, deal with inferiority complex, effect body modification, emancipation from slavery and to promote prostitution and fashion. Eradication of racial discrimination and the emancipation from slavery are factors that cannot be said to be a reason why women in the Zongo communities in Ghana bleach because they do not exist in that part of the world.

Durosaro, Ajiboye and Oniye (2012) also assert that the imminent need for young women to get attached to men and vice versa drive them to employ skin bleaching in order to attract their target. They did not fail to include married men and women however, because married men and women engage in skin bleaching to sustain their marriages and relationships. Kpanake et al (2010) are in support of this as they identified that people bleach in order to be more pleasurable, sensual and appreciated by their partners. Lewis et al (2011) are in total agreement with the view of Durosaro, Ajiboye and Oniye (2012) that women bleach their skins to satisfy or attract men as they discovered in their study that many women in Tanzania bleach because they believe Tanzanian men have a strong preference for lighter skinned women.

Konlan (2016) attributes the need to have flawless smooth skin tone to be the reason why women bleach as skin bleaching is perceived to present one flawless and smooth touch as well as remove dark spots from acne, get rid of acne itself as well as pigmentation. In the words of Lewis et al (2011) women bleach "to have soft skin".

Aseidu (2016) adds that the ease of accessibility and the affordability of skin lightening products have contributed to the reasons why women and men in Ghana bleach their skins. "The lack of contentment and understanding that God has a reason for creating us the way that pleases him is one of the reasons why people bleach their skins" in Warami's (2017) own words is the reason why women bleach. Lewis et al (2011) add that bleaching by women have escalated to this absurd level because skin bleaching products are readily available at low prices and over the counter.

In a study conducted by Lewis et al (2011) on the motivations of women in skin bleaching in Tanzania, the need to remove pimples, rashes and skin diseases is one of the motivating factors of skin bleaching among these women as they see these creams containing bleaching agents with sometimes unlawful levels of hydroquinone and mercury, mostly advertised on television as effective tools for curing skin problems. Another motivating factor they found out was the use of skin bleaching to counteract extended use which involves the use of the skin bleaching products to remove adverse effects of extended skin bleaching.

Lewis et al (2011) in their study again identified the need to satisfy and impress peers as one of the reasons women bleach in Tanzania. They reported the women experience strong societal pressures either directly or indirectly from their peers and even family. In a study conducted by Kpanake et al (2010), it is equivalent to their theme of 'compliance with others'. Rogers (2006) as cited in Kpanake et al (2010) reported one of the motives of skin bleaching as the need to enhance opportunities in life especially job opportunities. As light skinned persons are believed to have higher status, opportunities for education and jobs which reinforces Kpanake et al's (2010) theme of 'success' as a motive for skin bleaching. In a study conducted by Kpanake et al (2010) on the motives of skin bleaching in Togo, fashion was a theme identified by them as a motive for skin bleaching. Which they explained that most people bleach their skins because most top models they know are light skinned and also because it is a common practice.

\section{METHODOLOGY}

This study being qualitative, the research design that was adopted for it was the case study. Case studies emphasize detailed or in-depth contextual analysis of a limited number of events or conditions and their relationships. This study was conducted in selectived Zongo communities in Ghana which are Nima, Aboabo, Sawaba, Asawasi, and Madina. Zongo communities are found across all the ten regions in Ghana. The word 'zongo' itself is derived from the Hausa language which literally means "a settlement of Hausa speaking traders". A common feature of the Zongo communities is their predominant use of the Hausa language as their lingua franca. The largest and oldest of the Zongos close to the coastal belt started in 1836 in Nima. The zongos have a much denser population in the Ashanti and Greater Accra Regions. The population used in this study was women, young and old in the Zongo communities who engage or at a point in time in their lives engaged in the practice of skin bleaching. The purposive sampling technique was used to select all the 15 (fifteen) women, 
young and old in the Zongo communities in the country for the study. Purposive sampling is a non-probability sampling technique used to select a sample based on the characteristics of a population and the objective of the study (Crossman, 2018). To achieve the purpose of the study, the researcher used interviews (semi-structured interview guide) as instrument for gathering the necessary data for the study. The interviews served as the primary mode of data collection for the study. The thematic method of analysis was used in analysing data obtained from the interviews conducted.

\section{FINDINGS}

The thematic approach was used in the presentation of data where the different codes that were very similar and were considered as the same aspects within the data collected were explained under themes that were evident in the data collected and was essential in determining the feelings, thoughts and views of the interviewees. Interviews were held with 15 female participants who at the beginning were not finding it easy to explicitly express their feelings and thoughts.

The factors that influence women in these Zongo communities are numerous and could be intentional and/or unintentional. This was arrived at after the interviewees responded to the interview questions posted to them. Stories were told, experiences brought out and feelings of the respondents were expressed. The factors that influence women into bleaching or the reasons why women in these Zongo communities bleach their skins have been explained in the following themes.

(i) The attempt to treat Acne

(ii) The desire to sustain marriages

(iii) 'Fashion' and trends of beauty

(iv) Peer influence

(v) Influence from bleaching cream sellers

(vi) Attraction to the opposite sex

(vii) Influence from mothers

\section{The Attempt to Treat Acne}

This theme captures the struggle of some of the respondents to remove acne (pimples) from mostly their faces, their backs and chests. In answering the question on what motivated them to adopt skin bleaching, one of the respondent said,

I used to have lots of pimples on my face, chest and back. It was really disturbing me. It was sometimes painful and did not allow me to have the flawless skin every woman wanted to have. The pimples became even worse when I was on the verge of menstruating. Some of them were big in sizes (the pimples) and others were smaller. People used to question me about it whenever I made an appearance in public. Questions like 'why is your face so full of pimples', 'Why is your face so rough?' were thrown to me and that made me so frustrated and sad. So I had to resort to more powerful creams since the honey and 'lele' I was using did not help. I initially used 'funbact' A (A type of cream) to correct my pimples but upon using it, I realised my face, chest and back which were affected by the acne was becoming lighter but they appeared again on those areas when I stopped using it for some time. And so I had to buy creams to make my whole body lighter in order to achieve an even complexion. From then on, I can now go out without fear of being embarrassed and having to answer people's questions about my face. [sic]

Similarly, another respondent explained the ordeal she went through as a result of pimples on her face. She said, I used to have pimples on my face and chest. I went to the hospital several times. But even medicines at the hospital did not work. My face was so rough. And it was even worse when I'm on my period. It got to a time the pimples were so severe I couldn't go out. Not even to one of my best friend's marriage ceremony. But sometimes, the stupid questions some people will ask me about my face, it was as if I planted the pimples on my face by myself. Sometimes I ignore them. Other times I had to say something because it affected me emotionally. So I had to treat the pimples my own way. I started applying aloe Vera but the pimples just refused to disappear. But as much as some people were complaining about my pimples, others were giving me solutions. I remember how an acquaintance told me that the pimples were so much because of my dark complexion. She told me ladies who were fair people suffered less pimples. Upon observations, I realised it was indeed true because most of the fairer people I knew had less or no pimples at all. So I had to resort to making my skin fairer in order to reduce my pimples. [sic] When she was questioned on whether the bleaching solved her problem or not, she relied: "It worked really fine. My pimples disappeared as you can see." Only a few pimples in very small sizes were evident on her face as of the time of the interview which she explained was as a result of "pre-menstrual syndrome." This in fact meant that, according to them, when they became fairer or lighter, they were able to fight their problem of excessive acne disturbing them. 


\section{Desire to Sustain Marriages}

One of the factors that appeared in the data on factors that influenced women in Zongo communities to engage in skin bleaching was the attempt to sustain their marriages. This theme captured the respondents' intense will and determination to keep their marriages and prevent it from falling apart. One woman confessed that she changed her complexion in order to keep her marriage and to compete with her rival over their husband's attention.

"My husband no longer cared for me. But he was always pampering his other wife who was fair in completion and very beautiful. So I had to do something very fast. My husband started maltreating me but treated my rival so preciously. My problems with my husband were extremely serious to the extent that he sometimes did not leave me 'chop money'. I had confronted him by asking if I was being treated that way because I was less 'beautiful' in comparison to my rival. My husband had kept mute and since silent meant consent, I had also bought creams to change my complexion and was able to achieve almost the same 'beauty' as my rival." (sic)

Another woman explained when asked what motivated her to bleach her skin that:

"My husband's womanizing ways and fondness of fair women was why I bought creams to change my complexion. I had heard it from others that my husband chased after fair women and I also know very well how he liked fair children. He treated such children better than he did his own children. So in order to keep him to myself, I had to bleach my skin and that of my children. In fact, my children and I were using the same cream because a woman needs to do everything to keep her man."

The interviewees admitted that it helped them to an extent in keeping their husbands in check and also preventing divorce which they had sensed was slowly finding roots in their thoughts. The woman who had lost her husband's attention to her rival said she gained back his attention for a while.

“...he started treating me well so I'm sure that it was because of my colour. I don't think we will divorce as I initially thought."

Meanwhile, the other woman who had attributed her husband's womanizing and fondness of light skinned persons to her darker complexion said, "Even though I became light skinned my husband did not stop chasing women. In fact, it became worse. So I don't think it was because of my previous complexion. But I don't regret changing my complexion."

\section{'Fashion' and Trends of Beauty}

This theme covered the respondents' intense will to keep up to date with the 'fashion' and trends of beauty in their communities and the country as a whole. 'Fashion' and trends of beauty is a major motivation behind which many young women bleach their skins in the Zongo communities. Skin bleaching is a common practice.

A young married student explained that she had to keep up with the trend of having beautiful skin when she was about to marry. She said,

"You have to get very beautiful by having that smooth and flawless skin when you are getting married because it is one of the most important days of your life. Even your husband will appreciate it. You need to buy creams and apply to become pretty for your pictures and for your husband as well. Everyone is doing it." (sic)

From this it is evident that most brides go to the extent of getting a lighter or whiter skin which they call 'smooth and flawless' and almost every bride in these Zongo communities is involved in it to keep up with the trends in their community. Skin bleaching has become some sort of culture and a de facto practice in these communities where almost all women are enslaved by.

One other respondent replied,

Here in Nima, almost all the women have a fair complexion either natural or bleached. Whichever way, I don't really care and I do not see anything wrong with changing my complexion if everyone is doing it and it is my own body. Besides, I did not want to look odd and be subjected to weird looks, so I had to do it as well. (sic) She added that

If everyone is turning into lions and you do not turn into a lion as well, those who turn into it will come back to eventually devour you. You just have to follow the trend. Each generation comes with their own trend. This is ours. Can't you see even the celebrities are all having nice skin? It is because of the creams they use.

From the responses above, it can be concluded that in these zongo communities, beauty is equated to fair or light skin and somehow dark skin is seen as inferior to fair or white skin in terms of beauty.

\section{Peer Influence}

Another motivational factor that influences the women in the Zongo communities to bleach their skins is peer influence. Peer pressure in this context means direct or indirect pressure and influence from age mates or friends 
one associates with. In responding the question, "What was the motivation behind bleaching your skin?" One of the respondents replied

All my friends are fair and I am dark. Because of that I felt inferior when walking around with them especially when they gained all the attention on the streets from most men and even women. So I had no choice than to turn my darker skin into a lighter one using creams. (sic)

Another young girl who was a senior high school student when asked the same question recalled how her friends encouraged her to use creams to change her complexion. She said, "My friends recommended and even bought carowhite and neovate for me to use. At first, I did not want to do it but I had to because they were all fair."

In response to the same question, another woman recalled how her membership to a group influenced her to bleach her skin.

I was a member of a voluntary association in Aboabo which extended helping hands to its members during marriages, naming ceremonies and funerals. The women in the association all seemed to be light skinned. Whether it was either a natural one or a bleached one, I did not know. Since I wanted to join them and fit well in it, i had to change the creams I was using and bought ones that gradually gave me a lighter skin. I did this so that I will not to be seen as the deviant among them. (sic)

\section{Influence from Cream Sellers}

One other factor that influenced women in these Zongo communities into skin bleaching was the influence from cream sellers. In these Zongo communities, there are women who go around selling creams. They gave it to their customers either on 'cash and carry' or on credit basis. This was the response of one of the interviewees when she was asked the reason why she engaged in skin bleaching,

There is this woman who is my customer. She brings creams for me to buy. But the creams differ. I buy them because she is a cream seller. She knows the right creams for my skin and so it is only right I listen to her. It was in that process I earned my new (fair) complexion. It was not intentional at all.

The perception of these interviewees who buy from the cream sellers is that they (the sellers) know the right creams for them upon looking at their skins. Hence, it was only logical they listened to them when they tell which cream suits them. Another respondent said,

There is a friend of mine who owns a cosmetic shop. Whenever I go there, she shows me different kinds of creams and would tell me to buy them because it was good for my skin. I always listen to her because she knows much about her business. That was how I begun to become fair. And I like it.

One young woman stated that the woman she usually bought creams from would recommend some creams to her especially new ones on the market. She continued that, "the usual change of creams as recommended by the cream sellers made me light skinned. I trusted the cream seller and I also liked my new complexion. And so I continued with even other creams she advised me to use."

\section{Attraction to the Opposite Sex}

In order to attract men, most of the women in the Zongo communities engage in skin bleaching. The imminent need for these women especially the younger ones to end up with men of their choices and of good calibre make them alter their darker skins into lighter ones. One young married girl albeit with so much reluctance, opened up that "I had a friend who was fair and who usually attracted the attention of men wherever we went whiles I received less and less attention from men each day." She said,

I felt discriminated against and thought to stop associating with her as friend. But on a second thought, I realised disassociating with my friend would not help me so I resorted to bleaching my skin to get same attention as her friend got from men.

Another explained her own situation in the following words:

Initially, the men were not coming at all. It made me frustrated especially since my younger sister who took after my mother and was fair got married before I did. And so when I bought these pills and my complexion changed, I met my current husband afterwards.

"I felt unworthy and not enough of marriage a material when I had a darker complexion." She added.

\section{Influence from Mothers}

Another factor that manifested from the data on the motivation behind the bleaching of many women in the zongo communities was the influence from mothers. Mothers indirectly or directly influence their young female children into the practice of skin bleaching. One young girl, who was a senior high school student, revealed 
during the interview that, it was not her fault to bleach but her mother's. She said, My mother was using different creams and soaps to make her darker complexion fairer. Seeing my mother do it, I thought it was a good practice so I copied her. I also started using her creams secretly even though she asked me not to use her creams and soaps. I started to look just like my mother. My mother then started to buy it (creams) for me. So I became as beautiful as her.

This shows that some mothers are very much responsible for engagement of their female children in the practice of skin bleaching in the zongo communities. Either directly or indirectly most young girls are influenced into skin bleaching.

\section{RECOMMENDATIONS}

Based on the findings from the study, the following recommendations have been made:

The National Commission for Civic Education (NCCE) should take up the responsibility of educating women with emphasis on women in the Zongo communities using various platforms like the radio and television networks, festival grounds, social media as well as community to community talks and the mounting of billboards around the country using the 'shock therapy' by showing the endangering effects of skin bleaching on unfortunate victims as understanding brings prevention.

The Food and Drugs Authority (FDA) should not only make pronouncements on the ban of creams containing hydroquinone but should also declare a ban on mercury containing creams as it is as equally dangerous as hydroquinone and should also place bans on glutathione pills and injectables and ensure the ban is strictly implemented. The Food and Drugs Authority (FDA) should also ban the advertisement of bleaching creams and other agents on our various radio and television networks, get rid of billboards advertising it on our streets.

The government should turn its attention to local creams like Shea-butter and soaps like 'alata samina' by making policies that will enable them improve to suit the taste of our Ghanaian women.

Zongo community leaders like Imams, chiefs and queen-mothers of the various tribes in the zongo communities should use their respective platforms and positions to help educate their people to desist from the practice.

The Ghana Health Service (G.H.S) and various educational institutions should take up responsibilities of holding seminars, public talks, conferences and workshops at various parts of the country and particularly in the Zongo communities in the country on the impact of skin bleaching on individuals and the society as a whole.

\section{REFERENCES}

Akerele, A. (2006). The browning consensus. Observer Teenage Writer.

Akwei, I. (2017). Ghana implements new ban on hydroquinone. Retrieved on February $10^{\text {th }}, 2018$ from https://www.africanews.com/2017/05/18/ghana-implements-ban-on-import-sale-of-skin-bleachingproducts//

Ananpansah, B.A. (2016). Skin bleaching is a potential killer. Retrieved on November $4^{\text {th }}, 2018$ from http://m.modernghana.com/news/691746/skin-bleaching-is-a-potential-killer.html

Asiedu, K.G. (2016). Comfort used to bleach, now she has made a film about it. Retrieved on February $10^{\text {th }}$, 2018 from https://www.opera.pulse.com.gh/bi/lifestyle/black-barbie-film-comfort-used-to-bleach-now-shehas-made-a-film-about-it-id59222992.html

Carlos, L. (2016). The damaging effects of skin bleaching. Retrieved on November 4 ${ }^{\text {th }}, 2018$ from http://mobile.ghanaweb.com/ghanahomepage/features/the-damaging-efforts-of-skin-bleaching

Charles, C. (2003). Skin bleaching and social change. Retrieved on November $1^{\text {st }} 2018$ from http://www.academia.edu/1072264/skin-bleaching

Dankwah, C.O. (2005). Re: Bleaching and its effects among Ghanaians. Retrieved on November $4^{\text {th }}, 2018$ from $\mathrm{http}: / / \mathrm{m}$. modernghana.com/news/116218/re-bleaching-and-its-effects-among-ghanaians.html

Delle, E. (2016). Lifestyle: Ghanaian women now using cement to bleach. Retrieved on November $4^{\text {th, }} 2018$ from http://mobile.ghanaweb.com/ghanahomepage/entertainment/lifestyle:Ghanaian-women-now-using-cementto-bleach-419544

Durosaro, A.I., Ajiboye, S.K., \&Oniye, A.O. (2012).Perception of skin bleaching among female secondary school students in Ibadan metropolis, Nigeria. Journal of Education and Practice. Vol 3.

Engema, S. (2016).The dangers of skin lightening. Retrieved on February 10 ${ }^{\text {th }}, 2018$ from https://www.doktorsea.com/the-dangers-of-skin-lightening/

https://en.m.wikipedia.org/wiki/Category:Ghanaian-Zongo-people

Konlan, I. (2016). Skin bleaching: a silent killer of the youth of today. Retrieved on November $1^{\text {st }}, 2018$ from http://mobile.ghanaweb.com/ghanahomepage/entertainment/skin-bleaching-a-silent-killer-of-the-youth-oftoday-441001 
Kpanake, L. et al. (2010). Skin bleaching among Togolese: A preliminary inventory of motives. Journal of Black Psychology 36(3) 350-368

Lewis, M. K. (2011). Investigating Motivations for Women's Skin Bleaching in Tanzania. Psychology of Women Quarterly 35(1) 29-37.

Mahè, A., Ly, F., Aymard, G. \&Dnagou, J.M. (2003). Skin diseases associated with the cosmetic use of bleaching products in women from Dakar, Senegal. British Journal of Dermatology, 148(3).

Mire, A. (2001).Skin-bleaching: poison, beauty, power and the politics of color line.Academic Journal Article: Resources for feminist Research. Vol. 28, No. 3-4

Merriam-Webster Dictionary. (2018). Meaning of melanin. Retrieved on February 10 $0^{\text {th }}, 2018$ from https://www.merriamwebster.com/dictionary/melanin

Olumide, Y.M. (2006). Effects of skin bleaching on Nigerian men and women. International Journal of Dermatology. Vol. 67, No. 65-66

Warami, U. (2017). Skin bleaching liable for skin cancer, hypertension-dermatologist. Retrieved on February $10^{\text {th }}$ ，2018 from https://www.vanguardngr.com/2017/07/skin-bleaching-liable-skin-cancer-hypertensiondermatologist/

World Health Organization. (2011). Preventing diseases through healthy environments; mercury in skin lightening products. Geneva, Switzerland. 